\title{
Sampyuh: Genealogi Konflik Industri Ekstraktif di Lanskap Masyarakat Agraris
}

Oleh

\section{AB. Widyanta ${ }^{1}$}

\begin{abstract}
Abstrak
Berlatar gaduh ekonomi politik makro nasional, seputar renegosiasi kontrak tambang, tulisan ini hendak mengusung wacana tanding dari sudut bidik diametral, yaitu di tataran mikro kehidupan sosio-kultural warga seputar kawasan tambang. Upaya ini penting untuk memberikan kontra hegemoni atas diskursus politik makro yang cenderung bias ekonomi dan abai terhadap kompleksitas kehidupan warga, kekuatan politik riil, dengan segenap kontestasi kuasa multi-aktor di tingkat lokal. Berbasis pada systematisizing of experiences dari riset di kawasan tambang, tulisan terpilah ke dalam empat bagian: pertama, paparan akan mencuplik sekilas gaduh renegosiasi kontrak tambang termutakhir sebagai latar penjelas existing situation regulasi pertambangan di Indonesia. Kedua, tulisan akan membabar lini masa (timeline) berikut kronologi ringkas hadirnya Gold Mining Company (GMC) di "Bumi Timur". Ketiga, tulisan akan mendedahkan pembalikan gaya hidup dan laten konflik yang senantiasa membayangi kehidupan warga seputar kawasan tambang. Keempat, tulisan akan menyajikan sejumlah refleksi kritis dan peta jalan pembangunan perdamaian dan pembangunan berkelanjutan ke depan.
\end{abstract}

Kata kunci: konflik, industri ekstraktif, sumberdaya alam, dan sektor pertanian.

\begin{abstract}
Having the current debate about mining contract renegotiation that primarily using the angle of macro perspective of national political economy, this paper promotes a micro perspective analysis, describing socio-cultural life of people living around the mining site. This approach is important to balance the discourse of macro political analysis that tend to be economic bias and to be ignorance to the complexity of people life and the real political power with their multi-actor contest at the local level. Further, this paper is a note of reflection of the writer about the findings of field research undertaken using the method of in-depth interview with people living around gold mining site. Based on the result of systematization of experiences, the paper is divided into four sections as follows: first, a brief description about the latest debate on mining contract renegotiation as the background of the existing situation of the mining regulation in Indonesia. Second, the paper explains the timeline and the sort chronology of the existence of "Gold Mining Company" (GMC) in the "Bumi Timur" (Eastern Land). Series of important events happened at around the mining site is placed in the frame of the timeline. Third, the paper analyzes the reversal of the life style and the latent conflict that always haunt the life of people living around the mining site. Fourth, the paper presents critical reflections as inputs for the formulation of the road map of peace building and the outline of possible sustainable development.
\end{abstract}

Keywords: conflict, extractive industry, natural resources, and agricultural sector, collapse. ${ }^{1}$ AB. Widyanta, asisten dosen pada Jurusan Sosiologi Fisipol UGM dan asisten peneliti pada Pusat Studi Pedesaan
dan Kawasan (PSPK) UGM 
Jurnal Pemikiran Sosiologi Volume 2 No. 2, 2013

Sampyuh: Genealogi Konflik Industri Ekstraktif di Lanskap Masyarakat Agraris

AB. Widyanta

\section{A. Pendahuluan}

"Much of human history has consisted of unequal conflicts between the haves and the have-nots." Jared Diamond, 1998:93)

"Freedom in the commons does not produce a stable prosperity." (Hardin, 1994:199)

Setidaknya ada dua isu besar nasional yang mendominasi pemberitaan media masa pada kuartal pertama tahun 2014. Dua isu itu bisa diasosiasikan dengan demokrasi politik dan demokrasi ekonomi. Isu pertama terperagakan dalam serangkaian perhelatan Pemilu Caleg (Pileg) April 2014, sedangkan isu kedua terejawantahkan dalam serangkaian upaya penegakan "kedaulatan nasional atas sumberdaya alam", yaitu renegosiasi kontrak tambang.

Secara konseptual, kedua isu itu adalah abai terhadap kompleksitas kehidupan determinan penting bagi penegakan warga,kekuatan politik riil, dengan kehidupan berbangsa dan bernegara di segenap kontestasi multi-aktor di tingkat negeri ini. Sayang praktik demokrasi lokal. Sebagai antipode, tulisan ini akan ekonomi tidak menunjukkan kemajuan mendiskripsikan hasil refleksi penulis atas yang menggembirakan. Kebijakan hasil temuan riset melalui metode indepth renegosiasi kontrak tambang menuai interview dengan warga seputar kawasan resistensi kuat dari sekalangan perusahaan tambang-tambang

2http://finance.detik.com/read/2014/03/04/152328/2 514972/1034/larang-ekspor-tambang-mentah-jepangmau-adukan-ri-ke-wto kelas "kakap". Sebagian diantaranya menggancam dan berancang- ancang menyeret pemerintah Indonesia ke International Centre for Settlement of Investment Dispute (ICSID). ${ }^{2}$ Suka tidak suka renegosiasi kembali ditunda dan berlanjut lagi paska Pilpres (Pemilu Presiden) 2014.

Berlatar gaduh ekonomi politik makro nasional, tulisan ini hendak mengusung wacana tanding dari sudut bidik diametral, yaitu di tataran mikro kehidupan sosio-kultural warga seputar kawasan tambang. Upaya ini penting untuk memberikan kontra hegemoni atas diskursus politik makro yang cenderung bias ekonomi dan abai terhadap kompleksitas kehidupan warga, kekuatan politik riil, dengan segenap kontestasi multi-aktor di tingkat lokal. Sebagai antipode, tulisan ini akan mendiskripsikan hasil refleksi penulis atas hasil temuan riset melalui metode indepth interview dengan warga seputar kawasan tambang.

Selama hampir tiga dekade mengantongi kontrak karya, "Gold Mining Company" (GMC)—sebut saja demikian-telah sukses menyulap sebuah lanskap masyarakat agraris menjadi lanskap masyarakat "metropolis industrial" di sebuah kawasan perbukitan Bumi Timur Indonesia. ${ }^{3}$ Namun kekarutmarutan tatakelola di masa lalu telah menyebabkan "metropolis" mulai kehilangan pesonanya. Simptom-simptom sindrom kota hantu (ghost town syndrome) nampak semakin eskalatif. Terinspirasi pengalaman empiris itu serta provokasi efektif dari monografi kesohor "We Eat

\footnotetext{
3 Tulisan ini merupakan refleksi penulis atas hasil riset di seputar kawasan pertambangan. Demi mengindahkan kaidah/etika akademik, nama-nama orang dan tempat yang sebenarnya sengaja dirahasiakan dalam tulisan ini
} 
Jurnal Pemikiran Sosiologi Volume 2 No. 2, 2013

Sampyuh: Genealogi Konflik Industri Ekstraktif di Lanskap Masyarakat Agraris

AB. Widyanta

the Mine, The Mine Eat Us"4 - tulisan ini memilih cara pandang pesimistik, a la pembangkang antroposentrisme, bahwa di balik capaian gemilang materialisme industri ekstraktif, sejak itu pula pesona solidaritas kehidupan bersama dan kualitas ekologi masyarakat agraris mulai tercerabut, susut, dan redup. Banyak bukti empiris menunjukkan bahwa berkawin-mawinnya kelobaan dan teknologi-agresif niscaya memperanakkan petaka industrial. Tanpa berpretensi mengglorifikasikan romantisme masa silam, seluruh gagasan di tulisan ini lebih ditujukan untuk memformulasikan peta jalan menuju pemuliaan atas segenap berkah agar tidak mudah berbalik menjadi kutuk. Berkat suarasuara warga Bumi Timur Indonesia itulah tulisan ini mengada dan hadir di hadapan pembaca. ${ }^{5}$

Sesuara dengan para "neo-Gandhian" seperti Soejatmoko (1983), Schumacher (1974), Meadows (1972), Hardin (1983), Ostrom (2003), Constansa (2007), Diamond (2005), dan Brown (2011), tulisan ini hendak memproposisikan bahwa "sampyuh"6 adalah keniscayaan yang tak terpalingkan selama kekuatan politik negeri ini masih tersandera oleh dua preferensi berikut. Pertama, pembiaran atas beroperasinya paradigma ilmu ekonomi kekerasan (violence economics) ${ }^{7}$ yang akan berdampak pada percepatan laju pengurasan sumber-sumber alam tak terbaharui di

\footnotetext{
${ }^{4}$ June C. Nash, We Eat the Mines and the Mines Eat Us: Dependency and Exploitation in Bolivian Tin Mines. New York: Columbia University Press, 1997.

${ }^{5}$ Ucapan terimakasih sekaligus permohonan maaf penulis haturkan kepada semua warga yang telah sudi berbagi pada penulis perihal pembelajaran berharga ini meski tidak berbuah balas, bahkan untuk sekedar pencantuman nama sekalipun. Mea maxima culpa.

${ }^{6}$ Secara harafiah, sampyuh berarti mati di kedua belah pihak dalam pertempuran. Namun kata "mati" bisa ditafsirkan secara luas sebagai kejatuhan, kerugian,
}

negeri ini. Kedua, pelanggengan atas mentalitas dan kultur politik oligarki, dinasti, klientilisme yang akan berakibat pada peningkatan laju disparitas dan eksklusi sosial bagi warga miskin. Dua preferensi politik itulah yang akan menggiring bangsa ini ke kancah, meminjam Hardin, "tragedy of the unregulated commons." 8 Melalui metode sistematisasi pengalaman (systematisizing of experiences), pemaparan gagasan akan terpilah kedalam empat bagian berikut: pertama, paparan akan mencuplik sekilas gaduh renegosiasi kontrak tambang termutakhir sebagai latar penjelas kondisi terkini (existing situation) regulasi pertambangan di Indonesia. Kedua, tulisan akan membabar lini masa (timeline) berikut kronologi ringkas seputar hadirnya "Gold Mining Company" (GMC) di Bumi Timur. Dalam bingkai lini masa inilah alur peristiwa penting akan diletakkan. Ketiga, tulisan akan mendedahkan pembalikan gaya hidup dan laten konflik yang senantiasa membayangi kehidupan warga seputar kawasan tambang. Keempat, tulisan akan menyajikan sejumlah refleksi kritis yang bisa diracik dan diformulasikan menjadi peta jalan (road map) pembangunan perdamaian dan arah strategi pembangunan berkelanjutan ke depan.

kegagalan, keruntuhan, kebangkrutan, kerobohan, kelumpuhan, kehancuran, yang diakibatkan oleh relasi kausalitas-resiprokal dari dua atau lebih pihak dalam suatu kontestasi, kompetisi, dan konflik. Dalam tulisan ini, "sampyuh" bisa diasosiasikan dengan "collapse".

${ }^{7}$ Barbara Wood, E.F.Schumacher, His Life and Thought; New York: Harper \& Row Publisher, 1989, hlm. 361.

8 Garrett Hardin, The Tragedy of the Unregulated Commons dalam Trends in Ecology \& Evolution Volume 9 issue 5 1994, hlm.199. 
Jurnal Pemikiran Sosiologi Volume 2 No. 2, 2013

Sampyuh: Genealogi Konflik Industri Ekstraktif di Lanskap Masyarakat Agraris

AB. Widyanta

\section{B. Gaduh Renegosiasi Kontrak Tambang}

Lima tahun sejak disahkannya UU No.4 Tahun 2009 tentang Mineral dan Batubara (UU Minerba)sebagai pangganti UU No.11 Tahun 1967 tentang Ketentuan-Ketentuan Pokok Pertambanganproses renegosiasi Kontrak Karya (KK) dan Perjanjian Karya Pengusahaan Pertambangan Batubara (PKP2B), belum juga tuntas hingga saat ini. Jika mengacu amanat pasal 169 (b) UU No.4 Tahun 2009, renegosiasi kontrak karya itu mestinya sudah rampung pada tahun $2010 .{ }^{9}$

Bahkan pembentukan Tim Evaluasi untuk Penyesuaian KK dan PKP2B pun baru terjadi pada 10 Januari 2012, yaitu sejak terbitnya Keppres No 3 tahun 2012. Selaku ketua Tim Evaluasi, Menko Perekonomian, Hatta Rajasa, dan Mentri Energi dan Sumber Daya Mineral, Jero Wacik, bertugas merenegosiasikan enam klausul berikut: luas wilayah kerja, perpanjangan kontrak, penerimaan negara baik pajak maupun royalti, kewajiban divestasi, kewajiban pengolahan dan pemurnian di dalam negeri, serta kewajiban penggunaan barang dan jasa pertambangan dalam negeri.10

\footnotetext{
${ }^{9}$ Lihat Bab XXV Ketentuan Peralihan, Pasal 169 (b), UU No. 4 Tahun 2009.

10 Baca opini Hiski Darmayana, Quo Vadis Renego-siasi Kontrak Pertambangan dalam http://www.berdikarionline. com/opini/20140228/quo-vadis-renegosiasi-kontrak-pertambangan.html

11 Tania Murray Li, The Will to Improve: Governmentality, Development, and the Practice Politics, Duke University Press, 2007, hlm.4-5.

$12 \mathrm{~h} \mathrm{ttp}$ : / / w w w . ta mbangnew s . com / berit a / utama/3640-pemerintah-targetkan-renegosiasikontrak-karya-selesai-akhir-2013.html
}

Di tengah teriknya suhu politik Pileg dan Pilpres tahun 2014, gaduh akrobatik renegosiasi kontrak tambang atas nama "nasionalisme" dan "kesejahteraan rakyat" rupanya harus berakhir di jalan buntu yang sepi antusiasme publik. Alih-alih membangkitkan semangat nasionalisme dan kedaulatan, renegosiasi kontrak tambang justru menuai sinisme publik. Menggoreng isu "kedaulatan nasional atas sumber daya alam" di tahun politik adalah muslihat prematur kaum petahana guna mendulang suara warga belaka.

Ketidaksungguhan will to improve ${ }^{11}$-dalam artian sesuai dengan cita-cita demokrasi ekonomiterartikulasikan dalam serangkaian alibi banal yang menguras permakluman, kesabaran, dan kewarasan publik. Simak saja busa-busa celotehan yang meluncur secara inkonsisten ini: "Proses renegosiasi diharapkan akan dapat berakhir dan selesai selesai pada akhir 2013."12 "Kalau saya menilai melakukan renegosiasi tidak gampang."13 "Dari total 112 perusahaan, yang sudah selesai seluruhnya 25 perusahaan. Sisanya proses berjalan terus." 14 "Nanti kita teken lagi, habis Pemilu."15 "Saya optimis, proses selesai di 2014."16

\footnotetext{
${ }^{13}$ http://www.tribunnews.com/bisnis/2014/03/07/ menteri-esdm-renegosiasi-kontrak-tidak-gampang ${ }^{14}$ http://www.merdeka.com/uang/5-alibi-pemerintahsaat-gagal-paksa-freeport-renegosiasi.html ${ }^{15}$ http://bisnis.liputan6.com/read/2027893/usaipemilu-belasan-perusahaan-tambang-teken-renegosiasikontrak 16http://www.beritaheadline.com/jero-wacik-renegosiasi-kontrak-selesai-tahun-ini
} 
Jurnal Pemikiran Sosiologi Volume 2 No. 2, 2013

Sampyuh: Genealogi Konflik Industri Ekstraktif di Lanskap Masyarakat Agraris

AB. Widyanta

Separoh dekade berlalu, amanat renegosiasi berakhir dengan tangkapan "teri". Sementara durasi perburuan "kakap" terkesan diulur dan diperlonggar guna memperlebar celah dan peluang bagi para oligark untuk meraup rente. Memanfaatkan ketidakpastian dan ketidakstabilan regulasi maupun aturan-aturan turunannya yang panjang, rumit, dan berbelit menjadi modus operandi yang sudah sangat lazim. ${ }^{17}$ Perburuan melibatkan multi (oknum?) aktor, agensi, dan jenjang struktural, mulai dari pemerintah pusat hingga daerah. Daya jangkitnya pun menjalar di antara para pejabat, birokrat, aktor di sektor privat, hingga rakyat. Persis di dalam gulitanya labirin palung-palung renegosiasi itulah tujuan mulia konstitusi gampang tersandera. Tragisnya, sejarah senantiasa berulang bahwa amanat acap berujung khianat.

Apa yang absen dari kisruh renegosiasi kontrak tambang adalah keseriusan pelibatan terhadap setiap perkara detil dan substil. Dalam regulasi politik makro yang gandrung determinisme ekonomi, para aparatus negara di tingkat pusat begitu piawai mengkalkulasi penerimaan fiskal dari pajak dan royalti tambang, seperti tercermin dalam enam klausul renegosiasi, namun abai terhadap kalkulasi yang detil dan substil atas karut marut psiko-sosio-kultural-ekologis warga seputar kawasan tambang. Pemerintah daerah juga tak kalah bengis dalam memperagakan "neo-liberal governmentality" yang sarat dengan budaya politik oligarki, dinasti, dan klientilisme, hingga ingkar terhadap hak-hak warga.

${ }^{17}$ Menyoal keruwetan regulasi minerba, baca Faisal Basri, Akrobat Larangan Ekspor Mineral Mentah, Opini Kompas, Senin 20 Januari 2014.
Di lain sisi, sebagai entitas privat bercredo profitoriented, perusahaan sangat handal dan luwes memainkan peran "mimikri" yang setiap saat siaga beradaptasi dengan perubahan kondisi sekitar. Sejauh tak mengusik credo, ia akan gesit berselancar di antara kepungan gelombang regulasi yang fluktuatif sekalipun. Jika jebakan ekstrim tak lagi tertanggungkan, barulah ia menggandalkan ilmu pamungkasnya: "jurus langkah seribu”. Itulah sebab, ia begitu kesohor dengan julukan " $a$ footloose industry" dalam pengertian yang peyoratif.

Segundukan bukti empiris dari segenap penjuru negeri ini menunjukkan bahwa keseharian hidup warga seputar tambang rentan terpapar beragam persoalan seperti pencaplokan lahan, perusakan lingkungan, deforestasi, ketidakadilan, konflik, eksklusi sosial, ketimpangan sosial, degradasi kultural, dan lain sebagainya. Melampui ciutnya kepentingan ekonomi makro, pada basis prioritas itulah renegosiasi kontrak tambang mestinya diletakkan. ${ }^{18}$

Situasi itu mengingatkan kita tentang petitih purba "the devil's in the details". Setiap ihwal terkecil dan substil merupakan elemen penentu terpenting dari suatu mahakarya. Kealpaan kecil di permulaan adalah cilaka di paripurnanya. Bagaimanapun tata hidup bersama membutuhkan aparatus negara yang mengindahkan pesan dari para bijak bestari: "Duc in Altum!" Bertolaklah dari hal yang paling dalam. Tanpanya, tata hidup bersama akan mudah tergelincir menjadi ajang pertarungan asimetris

18 Untuk paparan renegosiasi yang kontekstual baca Ferdy Hasiman, Renegosiasi dan Kuasa Korporasi, Opini Kompas, Jumat 14 Maret 2014 
Jurnal Pemikiran Sosiologi Volume 2 No. 2, 2013

Sampyuh: Genealogi Konflik Industri Ekstraktif di Lanskap Masyarakat Agraris

AB. Widyanta

yang bengis antara mereka yang kaya dan yang melarat. 19

\section{Lini Masa Industri Ekstraktif di Bumi Timur20}

"Gold Mining Company" (GMC) adalah perusahaan yang mayoritas sahamnya dimiliki oleh empat perusahaan dari Indonesia. Sedangkan operator proyek penambangan ditangani oleh dua perusahaan raksasa dunia. Dua perusahaan inilah yang bertindak sebagai operator GMC di kawasan utama lingkar tambang di wilayah perbukitan Bumi Timur. Luas lahan gabungan GMC sendiri mencapai kurang lebih 1 juta hektar.

Secara umum tahapan usaha tambang bisa dirinci dalam sejumlah tahapan berikut. Eksplorasi, studi kelayakan, persiapan penambangan (pembangunan infrastruktur), penambangan (eksploitasi), pengolahan bahan galian, pengangkutan, dan pemasaran. Secara kronologis, periodisasi pengembangan GMC di Bumi Timur bisa disederhanakan ke dalam tiga periodeberikut.

Pertama, periode tahun 1980an, GMC melakukan penandatanganan kontrak karya pertambangan di wilayah Bumi Timur. Pada periode ini GMC mengawali proses kajian awal, eksplorasi, dan studi kelayakan. Kedua, periode 1990an, GMC masih melanjutkan eksplorasi dan studi kelayakan dan kemudian masuk ke persiapan penambangan (pembangunan konstruksi). Ketiga, periode tahun 2000an, GMC melakukan penambangan (eksploitasi), pengolahan, pengangkutan, dan pemasaran.

${ }^{19}$ Jared Diamond, Guns, Germs and Steel: A short history of everybody for the last 13,000 years., Lon-don: Vintage, 1998, hlm.93.
Pada periode pertama, latar kehidupan warga pada periode ini, lanskap Bumi Timur masih berupa hutan belantara dan sebagian lainnya merupakan lahan pertanian warga. Selain aktivitas utamanya bercocok tanam (padi dan palawija) di ladang tadah hujan, mayoritas warga adalah para peternak kuda dan sapi yang jumlahnya bisa mencapai belasan. Luas dan suburnya padang penggembalaan memungkinkan warga memelihara ternak dengan cara melepas tanpa perlu kandang. Selain hemat tenaga, waktu luang bisa mereka gunakan untuk berburu rusa, mencari madu hutan, daun dan akar tanaman obat. Meski terbatas warga masih melakukan aktivitas berburu dan meramu.

Di kawasan ini, desa-desa terpencar berjauhan dengan tingkat kepadatan penduduk yang masih sangat rendah. Misalnya, salah satu desa tertua, sebut saja Malakas, hanya dihuni tidak lebih dari 120 jiwa pada era 1970an. Dalam perjalanan waktu jumlah itu nantinya melonjak sebesar delapan kali lipat menjadi $240 \mathrm{KK}( \pm 1000$ jiwa) pada dekade 1980an. Hingga di kemudian hari nanti populasi meledak menjadi $6.000 \mathrm{KK}$ ( \pm 24.000 jiwa) pada dekade 2000an.

Berbekal surat izin dari pemerintah pusat dan provinsi, GMC mulai melakukan proses eksplorasi dan studi kelayakan. Selain mengkaji area-area deposit mineral, GMC mulai melakukan pendekatan kepada para warga desa sekitar kawasan yang akan terdampak. Fragmentasi warga mulai terjadi. Respon warga terbelah setidaknya dalam tiga

20 Nama-nama perusahaan, tempat, wilayah, dan orang yang disebut/digunakan dalam tulisan ini bukan nama sebenarnya (alias) 
Jurnal Pemikiran Sosiologi Volume 2 No. 2, 2013

Sampyuh: Genealogi Konflik Industri Ekstraktif di Lanskap Masyarakat Agraris

AB. Widyanta

kelompok berikut: kelompok yang mendukung, kelompok yang menolak, dan kelompok yang apatis.

Pertama, kelompok warga yang mendukung proyek cenderung berpikiran praktis bahwa mereka akan mendapat manfaat langsung dengan adanya proyek tersebut. Status ekonomi kelompok pendukung ini terdiri dari warga yang berasal dari kelas elit dan menengah. Kedua, kelompok warga yang menolak proyek terkategorikan lagi kedalam dua varian yang berbeda yaitu: 1). Kelompok yang berfikir tradisional dan merasa khawatir nilai-nilai sosial dan lingkungan yang mereka miliki dan pelihara selama ini akan rusak. Kelompok ini terdiri dari warga dari kelas ekonomi bawah; dan 2). Kelompok yang merasa tidak mendapatkan akses atau manfaat langsung dari proyek. Kelompok ini terdiri dari warga kelas ekonomi menengah yang merasa menjadi tokoh. Kelompok ini relatif memiliki pengaruh dan kemampuan agitasi terhadap warga lainnya. Ketiga, kelompok yang apatis terhadap proyek terdiri dari warga yang menyadari bahwa mereka tidak memiliki kemampuan bertindak dan hanya menerima/pasrah saja pada perubahan yang mungkin akan terjadi. Kelompok ini terdiri dari warga kelas ekonomi bawah.

GMC akhirnya berhasil menuntaskan proses negosiasi dengan warga. GMC berhasil membujuk warga Desa Malakas (sejumlah 120 KK) untuk pindah ke pemukiman baru yang telah disiapkan. Migrasi warga terjadi sebanyak tiga kali sebelum akhirnya benar-benar menetap di pemukiman yang saat ini mereka tempati. ${ }^{21}$
Periode kedua, GMC mulai masuk ke tahapan persiapan penambangan atau pembangunan infrastruktur. Latar kehidupan sosial pada tahapan ditandai dengan terjadi perubahan yang sangat masif di seluruh kawasan. Memanasnya suhu politik makro nasional, pra dan paska reformasi 1998, menjadi latar penjelas atas absennya negara di seputar kawasan tambang. Ketiadaan intervensi negara menyebabkan ketidakjelasan perencanaan, arah sasaran, dan strategi pencapaian yang memadai.

Gegar budaya (cultural shock) menjadi keniscayaan. Masuknya para buruh migran dari beragam suku, agama, ras, etnis berkontribusi pada potensi dan kerawanan konflik yang sewaktu-waktu siap meledak menjadi konflik terbuka. Konflik antara warga lokal dengan warga pendatang dan konflik antar kelompok-kelompok pendatang menjadi penanda awal periode ini. Selain konflik sosial, permasalahan lain yang timbul pada periode ini adalah tekanan pada lingkungan. Kebutuhan ruang untuk tinggal, kebutuhan pasokan bahan pangan, air bersih telah menjadi persoalan krusial. Untuk memenuhi berbagai kebutuhan itu, GMC menunjuk perusahaan-perusahaan sub-kontraktor memberikan layanan.

Ada satu catatan penting yang perlu diungkap di sini, para warga telah berandil besar dalam penyediaan pemukiman dengan secara mandiri tanpa adanya stimulasi dana sama sekali dari GMC. Dengan cara berhutang, para warga membangun kamar-kamar untuk disewakan kepada para buruh tambang. Padahal menurut ketentuan, pembangunan pemukiman mestinya dilakukan oleh perusahaan

\footnotetext{
21 Wawancara warga (Habr), 2 November 2013
} 
Jurnal Pemikiran Sosiologi Volume 2 No. 2, 2013

Sampyuh: Genealogi Konflik Industri Ekstraktif di Lanskap Masyarakat Agraris

AB. Widyanta

tambang, bukan oleh warga semacam itu. Hal itu mengindikasikan bahwa para warga justru mensubsidi GMC. ${ }^{22}$

Periode ini juga ditandai dengan masuknya sejumlah perusahaan sub-kontraktor yang banyak membutuhkan tenaga kerja konstruksi. Mayoritas warga terserap di sektor industri. Hal itu menyebabkan berkurangnya tenaga kerja produktif di sektor pertanian. Aktivitas pertanian tinggal digeluti oleh mayoritas warga yang berusia di atas 50 tahun. Disini terjadi diskontinuitasmasyarakat agraris, sebuah keterputusan generasi. Ketika itu GMC sudah melaksanakan program Corporate Social Responsibility (CSR) yang sebenarnya bisa diprioritaskan untuk menyangga kemerosotan di sektor pertanian. Sayang GMC banyak terjebak pada program CSR yang elitis dan bersifat top down. Dana CSR disalurkan kepada kelompok-kelompok elit dan menengah yang sebelumnya menjadi kelompok pendukung. ${ }^{23}$

Periode ini bisa dicatat pula sebagai awal terjadinya praktik pembajakan kaum elit (elit capture) yang dilakukan secara berjenjang mulai dari aparat pemerintah pusat, provinsi, kabupaten, kecamatan, hingga desa, tanpa kecuali di tataran masyarakat sipil. Terjadi penyelewengan dana CSR yang cukup besar oleh praktik nepotisme dan kronisme di Departemen Humas \& Pembangunan Komunitas GMC dan sejumlah Lembaga Swadaya Masyarakat (lokal) di Bumi Timur. Berbagai skandal itu semakin memperparah dampak dan tekanan pada kehidupan warga seputar kawasan tambang. Segenap

\footnotetext{
22 Wawancara warga (Sjrw), 1 November 2013

23 Program-program CSR yang bersifat benevolent, Testimoniwarga (Sjrw \& Hmz), 1 November 2013
}

kekarutmarutan itu tidak mengalami perubahan yang berarti hingga periode ketiga nanti. ${ }^{24}$

Periode ketiga, latar kehidupan sosial pada tahap penambangan (ekploitasi) ini sangatlah kompleks. Tapi secara garis besar, meruyaknya beragam persoalan sosial pada periode ini merupakan akumulasi persoalan masa sebelumnya yang tidak terurus dan terkelola dengan baik. Selain karena lumpuhnya kelembagaan pemerintah desa, hal itu juga disebabkan karena tidak adanya barrier kelembagaan sosial di tingkat lokal yang mampu mengajukan koreksi-koreksi kritis terhadap jalannya pembangunan maupun berperan sebagai jejaring pengaman sosial warga. Selain telah terfragmentasi, segenap lembaga adat, kelompok tani, kelompok karangtaruna, dan kelompok sosial lainnya berjalan nyaris tanpa visi. ${ }^{25}$

Tidak adanya benteng kelembagaan lokal menyebabkan problem sosial terus berlanjut dan semakin akut. Salah satu eksemplar riil adalah semakin terpinggirkannya masyarakat lokal, tertama petani, ke wilayah pinggiran. Warga lokal yang tidak sanggup bertahan dalam kancah kompetisi yang bengis, perlahan-lahan mulai mengisolasi diri ke wilayah pinggiran (sekitar kawasan hutan). Sebagian bahkan karitatif, topdown, bias-fisik, dan non-pemberdayaan semacam itu banyak dipilih karena lebih menguntungkan bagi para kroni. Kebutuhan warga bukanlah prioritas penting bagi kroni-kroni yang bercokol di sejumlah LSM bentukan GMC menjadi kelompok rentan di wilayahnya sendiri. ${ }^{26}$
24 Wawancara warga (Hmz), 1 November 2013

${ }^{25}$ Wawancara warga (Sjrw), 1 November 2013

26 Wawancara warga (Wgm), 3 November 2013. 
Jurnal Pemikiran Sosiologi Volume 2 No. 2, 2013

Sampyuh: Genealogi Konflik Industri Ekstraktif di Lanskap Masyarakat Agraris

AB. Widyanta

Lebih jauh, kultur kerja industrial menyebabkan tekanan psikologis yang berlebih pada para karyawan perusahaan. Kondisi itu membuka peluang ekonomi bagi para investor. Maka pada periode inilah sejumlah café dengan segenap paket hiburan yang lengkap (miras, perjudian, prostitusi) mulai menjamur. Penolakan pun muncul dari warga lokal, terutama kelompok kelas bawah yang sejak awal menolak dan apatis terhadap tambang. Tegangan di antara kelas elit dan kelas bawah terus berlangsung. Sementara aparat keamanan turut memainkan tegangan sosial itu demi memburu rente dari bisnis keamanan. ${ }^{27}$

Penanda lain yang cukup menyolok adalah meningkatnya kontestasi dalam mengakses pekerjaan di sektor industri. Banyak warga telah melego tanah pertanian ke makelar, sekadar menuruti keinginan anaknya bisa bekerja sebagai buruh perusahaan (subkontraktor, kontraktor, GMC). Mereka yang memiliki banyak uang/koneksi ke perusahaan pastilah akan mendapatkan akses pekerjaan. Pendek kata, konflik ketenagakerjaan mengalami eskalasi yang menyolok. Serangkaian demostrasi dan protes warga yang bermula sejak 2009 mencapai titik kulminasinya pada tahun 2011. Tidak lolosnya sejumlah pemuda Desa Sengkengken ${ }^{28}$ dalam seleksi tenaga kerja GMC telah

\footnotetext{
27 Wawancara warga (Gun), 2 November 2013.

${ }^{28}$ Desa Sengkengken adalah desa yang mayoritas be-sar warganya merupakan warga asli/lokal. Ketidak-puasan terbesar pada GMC berasal dari wilayah desa ini. Dari sekitar $1000 \mathrm{KK}$ di desa itu, sebanyak 500 warga bekerja di GMC maupun perusahan-perusa-haan subkontraktor dan kontraktornya.

29 Mayoritas warga berkeyakinan bahwa pekatny kronisme dalam manajemen GMC berkontribusi besar pada ketidakjelasan rekruitmen tenaga kerja. Kebijakan Daftar Tunggu tetap tidak bisa bekerja efektif, ketika GMC hanya bertindak seperti laiknya "pemadam kebakaran"
}

memicu demonstrasi besar-besaran hingga memblokir dan melumpuhkan jalur transportasi publik satu-satunya di sisi timur area pertambangan. Konflik bisa diredam dengan dikeluarnya Kebijakan Daftar Tunggu (rekruitmen) dari GMC. ${ }^{29}$

Penanda lain yang cukup penting pada periode ini adalah munculnya "skandal nasional divestasi" yang turut menyeret pejabat tinggi kabupaten Bumi Timur. ${ }^{30}$ Penanganan kasus tidak tuntas dan menyisakan teka-teki hingga kini. Bahkan kasus telah terkubur oleh kasus termutakhir, yaitu kisruh renegosiasi kontrak tambang, dimana tenggat waktunya berakhir pada 12 Januari 2014 lalu. Ketidaktegasan Tim Evaluasi membuat renegosiasi kontrak karya semakin enigmatik dan penuh ketidakpastian.

Hingga tulisan ini dibuat, aktivitas penambangan merosot drastis. Selain menawarkan paket pensiun dini kepada para buruh, GMC juga mengurangi porsi atau shift kerja setiap buruh dari yang semula 22 hari kerja menjadi tinggal 4-8 hari kerja per bulan. Kebijakan itu berlaku hingga batas waktu yang tidak ditentukan. Di satu sisi, merosotnya penghasilan tentu merupakan kebuntungan bagi mereka yang biasa hidup mewah dan royal. ${ }^{31}$ Demi bertahan hidup mereka kini terpaksa menjual barang-

tanpa ada upaya sistematis, transparan, dan berkeadilan dalam rekruitmen tenaga kerja.

30 Tak adanya regulasi tentang divestasi telah mengakibatkan potensi kerugian Indonesia mencapai Rp.8,8 Trilyun.

31 Diperkirakan hanya 10 persen dari seluruh warga lokal (buruh tambang) yang mampu mengelola dan mengembangan pendapatan mereka untuk usaha produktif. Testimoni warga (Mrn), 12 Februrari 2014 Mayoritas warga berkeyakinan kuat bahwa perbaikan konstalasi politik nasional paska Pilpres 2014 akan berdampak pula pada pulihnya segenap aktivitas pertambangan di Bumi Timur. 
Jurnal Pemikiran Sosiologi Volume 2 No. 2, 2013

Sampyuh: Genealogi Konflik Industri Ekstraktif di Lanskap Masyarakat Agraris

AB. Widyanta

barang berharga yang masih tersisa, sembari menanti kembalinya nasib baik paska Pilpres 2014 mendatang. ${ }^{32} \mathrm{Di}$ lain sisi, sebagian warga bisa menyikapinya secara lebih realistis, sembari mengkalkulasi berbagai peluang lain untuk penghidupan mereka ke depan. Identifikasi potensi tertuju kembali ke sektor pertanian dan peternakan, budidaya tanaman Sisal (Agave sisalana Parrine), atau merintis sektor jasa pariwisata pantai. ${ }^{33}$

\section{Antipode: Pembalikan Gaya Hidup}

Terjadinya perubahan budaya dan gaya hidup warga tidak bisa dipisahkan dari dua faktor utama berikut ini: pertama, merangseknya ekspansi ekonomi kapitalistik (ekonomi pasar/ekonomi uang) dan kedua, persilangan budaya yang dibawa para warga pendatang (migran). Berkelitberkelindannya dua faktor tersebut telah mengubah secara drastis kehidupan sosial warga, seperti: budaya kerja, konsumerisme, poligami, perilaku berisiko, merosotnya gotongroyong/solidaritas sosial, dll. Tilikan atas itu bisa disimak dalam paparan berikut.

Hempasan gelombang ekonomi kapitalistik yang terepresentasikan dalam ekonomi pasar/uang telah mengubah hampir seluruh aspek kehidupan warga. Mekanisme pasar yang volatil (mudah goyah, labil) kian merongrong pondasi perekonomian desa. Dalam hitungan satu setengah dekade saja, ekonomi pasar telah merobohkan sistem ekonomi subsisten. Berbagai sistem kelembagaan, alat, dan

\footnotetext{
32 Mayoritas warga berkeyakinan kuat bahwa perbaikan konstalasi politik nasional paska Pilpres 2014 akan berdampak pula pada pulihnya segenap aktivitas pertambangan di Bumi Timur.
}

faktor produksi di sektor pertanian menjadi tersingkir dan marjinal. Merosotnya kuantitas dan kualitas lahan pertanian, berkurangnya jumlah petani, rendahnya peran kaum muda di sektor pertanian menjadi konsekuensi logis yang sulit ditampik.

Perubahan pola kerja agraris ke industrial juga telah mengubah relasi sosial masyarakat. Tuntutan kedisiplinan dan profesionalitas kerja di sektor industri telah mencerabut kaum muda produktif dari desa. Jadwal kerja yang berlangsung dari pukul 05.00 hingga pukul 17.00 membuat tenaga muda produktif kehilangan peluang untuk terlibat dalam pembangunan desa. Proses depolitisasi kaum muda mengakibatkan desa mengalami kevakuman (brain drain) gagasan, inisiatif, dan tenaga produktif bagi pembangunan. ${ }^{34}$

Dikomparasikan dengan sektor pertanian, beragamnya lapangan kerja baru di sektor industri membuka peluang yang luas bagi tenaga produktif untuk mengakses pekerjaan dan pendapatan ekonomi yang jauh lebih tinggi. Hanya saja, peningkatan pendapatan tidak selalu berkorelasi dengan perbaikan kesejahteraan.Peningkatan pendapatan ternyata telah menstimulasi kesadaran warga untuk menggeser makna dan konsepsi tentang "kebutuhan" itu sendiri. Peningkatan pendapatan telah mendongkrak tingkat konsumerisme warga. Hal itu bisa dicermati pada berbagai kasus kepemilikan kendaraan bermotor (sepeda motor dan mobil), alat-alat elektronik, dan

\footnotetext{
${ }^{33}$ Wawancara warga (Hmz), 11 Februari 2014

34 Wawancara warga (Habr), 2 November 2013
} 
Jurnal Pemikiran Sosiologi Volume 2 No. 2, 2013

Sampyuh: Genealogi Konflik Industri Ekstraktif di Lanskap Masyarakat Agraris

AB. Widyanta

barang-barang konsumtif lainnya yang cenderung melampaui batas guna. Cara warga berpakaian yang sangat demonstratif dan menyolok adalah manifestasi lainnya. ${ }^{35}$ Lebih celaka lagi, mayoritas buruh perusahaan membelanjakan uangnya di mal-mal kota besar di luar pulau Bumi Timur. Baik mineral tambang maupun peredaran uang terekstraksi ke luar pulau. Maka tidak mengherankan jika perekonomian lokal tidak bisa berkembang dengan baik. ${ }^{36}$

Perbedaan tingkat konsumsi antara kelas atas dan kelas bawah itulah yang menjadi salah satu pemicu kecemburuan sosial warga. Disparitas sosioekonomi warga, antara yang bekerja dan yang tidak bekerja di perusahaan tambang (subkontraktor/kontraktor/GMC) terlalu menyolok dan terjadi di semua desa seputar kawasan tambang. ${ }^{37}$ Ekspansi ekonomi pasar memposisikan para warga yang berdaya beli rendah sebagai kaum yang tidak teruntungkan dan bahkan semakin mengalami deprivasi ekonomi dan sosial di masyarakat. Ketika para penjual ikan dan sayuran datang ke desa, misalnya, kaum kaya biasanya tidak pernah menawar karena daya belinya tinggi. Mekanisme pasar semacam itu jelas membuat "buntung" warga yang berdaya beli rendah. ${ }^{38}$

Kasus lain tentang perubahan gaya hidup para buruh di sektor industri ekstraktif adalah soal poligami. ${ }^{39}$ Kasus ini meningkat pada periode ketiga (tahun 2000an). Tingginya penghasilan telah memicu terjadinya praktek poligami di kalangan

35 Wawancara warga (Mrn), 2 November 2013

36 Wawancara warga (Hmz), 31 Oktober 2013

37 Wawancara warga (Kds), 3 November 2013.

38 Bandingkan Henk A. Becker and Frank Vanclay, The International Handbook of Social Impact Assessment: warga, terutama yang bekerja di GMC. Suami memiliki 2 hingga 3 istri merupakan hal yang sudah sangat umum. Tidak jarang para perempuan yang dimadu itu berasal dari satu wilayah desa yang sama. Mereka hanya bisa bersikap pasrah. ${ }^{40}$ Praktek poligami ini terjadi karena lemahnya posisi tawar kaum perempuan dihadapan kaum laki-laki yang memonopoli basis-basis material keluarga.

Lebih jauh, berbagai bentuk perilaku yang berisiko juga menjadi fenomenayang dominan pada periode awal hingga pertengahan tahun 2000an. Migrasi besar-besaran para buruh pertambangan telah melahirkan persoalan sosial yang kompleks di desadesa seputar kawasan tambang. Konsumsi minuman keras, narkoba, perjudian, kriminalitas, prostitusi, aktivitas seksual yang berisiko menimbilkan gejolak sosial dan keresahan warga. Persoalan sosial yang paling mengkhawatirkan pada periode ini adalah ancaman penularan penyakit menular seksual (PMS) dan HIV/AIDs. Beragam perilaku sosial urbanomic tersebut telah menimbulkan culture shock bagi warga desa seputar tambang. Terhitung sejak 2007, berbagai persoalan sosial itu bisa disolusikan dengan baik, berkat keseriusan dan penanganan intensif dari mutli-stakholder. ${ }^{41}$

Perilaku atomistis, individualis, dan pragmatis yang terkonstruksikan melalui kultur kerja industrial semacam itu secara tidak langsung telah menggerogoti bangunan kohesi sosial masyarakat. Sebagian besar warga menegaskan bahwa tingkat kegotongroyongan sudah mulai luntur. Sangat sulit

Conceptual and Methodological Advanc-es, Cheltenham: Edward Elgar, 2003, hlm. 81-82.

39 Wawancara warga (Habr), 2 November 2013.

40 Wawancara warga (Mcw), 30 Oktober 2013

41 Wawancara warga (Shbd), 2 November 2013. 
Jurnal Pemikiran Sosiologi Volume 2 No. 2, 2013

Sampyuh: Genealogi Konflik Industri Ekstraktif di Lanskap Masyarakat Agraris

AB. Widyanta

untuk mengumpulkan atau meminta bantuan warga. ${ }^{42}$ Kasus paling menyolok terjadi di Desa Malakas. Terkonsentrasinya mayoritas besar pendatang di Desa Malakas turut berimbas pada melemahnya kegotongroyongan warga dalam menjaga kebersihan lingkungan. Tidak sedikit warga yang beranggapan bahwa kebersihan lingkungan bukanlah tanggungjawab warga melainkan tanggungjawab GMC. Kian melemahnya tingkat kegotongroyongan warga disebabkan pula oleh pemerintah desa yang tidak proaktif. Alih-alih menjadi pelayan dan penggerak warga, mayoritas besar aparat desa justru disibukkan urusan bisnisnya sendiri. 43

\section{E. Peta Laten Konflik}

Tulisan berikut hendak mengupas konflik sosial warga seputar kawasan tambang. Karena peta konflik secara implisit telah tersaji pada paparan lini masa (timeline) industri ekstraktif, maka tulisan ini sebatas mempertajam dalam sejumlah simpulan pendek. Secara utuh, paparan tentang konflik akan menghampiri enam isu berikut: pertama, konflik sosial antara warga asli dan warga pendatang; kedua, kompetisi warga dalam mengakses pekerjaan, infrastruktur dan sumber daya alam; ketiga, perasaan warga atas ketidaksetaraan dalam perlakuan; keempat, perbedaan penghasilan dan akumulasi kesejahteraan warga; kelima, persaingan dan kecemburuan sosial di kalangan masyarakat;

42 Wawancara warga (Slmd), 1 November 2013

43 Wawancara warga (Drap), 31 Oktober 2013

${ }^{44}$ Konflik berbau SARA sengaja tidak diulas di ini, karena kasusnya yang sangat minor. Kasus terjadi di salah satu desa di dekat pelabuhan, sebut saja "Desa Bandana", dan keenam, pertambangan rakyat dan konflik sumberdaya. ${ }^{44}$

Keenam persoalan tersebut mengemuka sebagai fenomena sosial yang kompleks dan saling berkelit berkelindan. Jika ditilik menurut anatomi konflik ${ }^{45}$, keenam isu tersebut sesungguhnya hanyalah pemicu konflik saja. Sementara akar konflik sesungguhnya terletak pada lemahnya tatakelola bersama di antara multi-stakeholder terkait terhadap sumber daya alam maupun sumbersumber ekonomi produktif di seputar kawasan tambang yang sesungguhnya terbatas. Untuk anatomi konflik di seputar kawasan tambang bisa disimak pada bagan berikut.

dimana warga lokal melarang pemeluk agama minoritas melakukan peribadatan di wilayahnya karena dianggap tidak memiliki ijin.

45 Paul Wehr, Conflict Regulation; Boulder: Westview Press,1979, hlm. 18-22. 


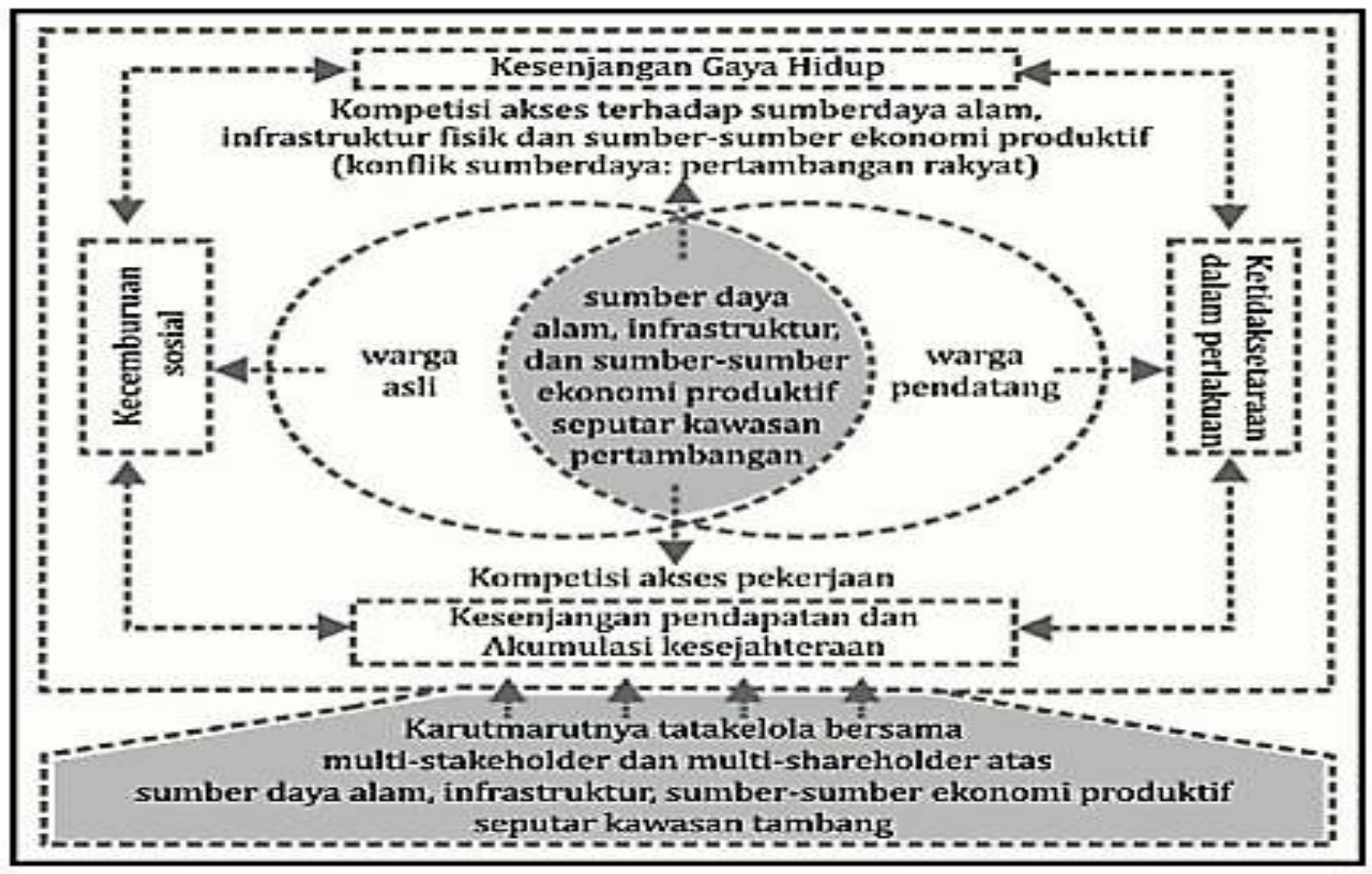

Gambar Skema Anatomi Konflik Seputar Kawasan

Tambang

Pertama, bibit konflik antara warga asli dan warga pendatang mulai terjadi sejak awal berlangsungnya proyek konstruksi (akhir tahun 1990an). Kendati proses adaptasi dan pembauran antar kelompok warga berlangsung relatif baik sejak tahun 2000an, namun isu ini selalu menjadi laten konflik yang siap menjadi konflik terbuka. Seiring menurunnya aktivitas penambangan yang dipicu ketidakjelasan regulasi, UU Minerba, indikasi konflik terbuka di Desa Malakas kembali meningkat pada tahun 2011.46
Kedua, kompetisi warga dalam mengakses pekerjaan, infrastruktur dan sumber daya alam terjadi hampir di seluruh desa seputar kawasan tambang. Maraknya protes/demonstrasi warga sejak 2010 merupakan cerminan dari peliknya persoalan ini. ${ }^{47}$ Pekatnya modus kolusi, kolusi, nepotisme (KKN) yang dilakukan para oknum, baik di perusahaan sub kontraktor, perusahaan kontraktor, maupun di dalam GMC sendiri, telah menyebakan rekruitmen tenaga kerja yang tidak 
Jurnal Pemikiran Sosiologi Volume 2 No. 2, 2013

Sampyuh: Genealogi Konflik Industri Ekstraktif di Lanskap Masyarakat Agraris

AB. Widyanta

transparan, tidak adil, dan tidak merata. ${ }^{48}$ Hal itu turut pula memicu persaingan usaha yang tidak sehat di antara kalangan kontraktor (nasional dan lokal) GMC, subkontraktor, dan supplier. Dalam ketidaktranspranan, pola kompetisi liberal yang berlangsung selama empat tahun terakhir benarbenar telah menyingkirkan para subkontraktor lokal. Rendahnya kapasitas pendanaan subkontraktor lokal tidak jarang menjadi ajang bagi para oknum untuk memainkan "proses mediasi" demi memburu rente. Segala sesuatunya bisa diatur dan dipermainkan, hingga tercipta persaingan ekonomi yang tidak sehat dan berbiaya tinggi. ${ }^{49}$

Ketiga, perasaan warga atas ketidaksetaraan dalam perlakuan. Baik warga asli dan warga pendatang sama-sama mengklaim bahwa mereka tidak diperlakukan secara adil dan setara. Warga asli mengungkapkan bahwa "Saya warga asli sini, saya berhak mencicipi, maka saya harus bekerja di sini. Kenapa orang lain bisa bekerja di sini, sementara warga lokal tidak." ${ }^{50}$ Di lain pihak, warga pendatang merasa diperlakukan tidak adil ketika beredar "surat edaran" Bupati yang mengharuskan kalangan perusahaan untuk mengurangi jumlah karyawan yang sudah bekerja di atas sepuluh tahun (terutama warga pendatang) dan menggantikannya dengan para karyawan muda yang sama sekali belum pernah mengenyam pekerjaan (terutaman warga asli). Kendati berprestasi, beretos kerja baik, dan tidak pernah memiliki catatan negatif, namun para buruh pendatang ini tetap diberhentikan oleh perusahaan dan digantikan dari warga lokal.51 Keempat, perbedaan dan akumulasi kesejahteraan

\footnotetext{
48 Wawancarawarga (Hmz), 31 Oktober 2013.

49 Wawancara warga (Sjrw), 1 November 2013

50 Wawancara warga (Ttn), 31 Oktober 2013
}

warga. Mayoritas warga desa seputar kawasan tambang mengamini bahwa telah terjadi ketimpangan kesejahteraan yang menyolok antara wara pendatang dan warga lokal. Kasus disparitas paling menyolok terjadi di enam wilayah desa yang menjadi sentra buruh migran, terutama Desa Malakas. Muncul kecenderungan kuat Desa Malakas menjadi "vacuum area" yang nyaris tanpa hadirnya intervensi negara maupun sektor privat. Di satu sisi, pihak pemerintah beranggapan bahwa Desa Malakas sudah ditangani oleh intervensi program CSR-GMC. Di lain sisi, pihak sektor privat, GMC, beranggapan bahwa mayoritas warga Desa Malakas adalah warga pendatang dan bukan lagi warga asli, sehingga tidak perlu lagi diprioritaskan. ${ }^{52}$

Kelima, persaingan dan kecemburuan sosial di kalangan masyarakat.Fenomena kecemburuan sosial terjadi merata hampir di seluruh desa seputar kawasan tambang. Kecemburuan sosial umumnya terjadi dari kalangan warga lokal terhadap warga pendatang. Kendati demikian, sentimen sosial itu tidak menimbulkan gejolak sosial yang mengancam kehidupan bersama. Pada kasus tertentu, sejumlah warga lokal yang tingkatan ekonominya rendah biasanya merasa inferior sehingga tergerak untuk menghindar dan mengelompokkan diri sesuai dengan kelas sosial mereka. Mereka menjual tanahnya yang di pusat desa dengan harga tinggi dan kemudian membeli tanah di pinggiran desa yang lebih murah. ${ }^{53}$ Manifestasi lainnya terartikulasikan dalam"rasanan" (pergunjingan) pada saat berlangsungnya kerja gotong-royong. Warga asli biasa mempergunjingkan warga pendatang

\footnotetext{
51 Wawancara warga (Abdr), 3 November 2013.

52 Wawancara warga (Hmz), 31 Oktober 2013

53 Testimoni warga (Ern), 3 November 2013.
} 
Jurnal Pemikiran Sosiologi Volume 2 No. 2, 2013

Sampyuh: Genealogi Konflik Industri Ekstraktif di Lanskap Masyarakat Agraris

AB. Widyanta

(kaya) yang tidak pernah hadir dalam kerja bakti tapi hanya menyumbangkan uang dengan nominal tertentu. ${ }^{54}$

Keenam, pertambangan rakyat dan konflik sumberdaya. Pertambangan rakyat merupakan aktivitas penambangan emas yang dilakukan warga di sejumlah area milik pribadi seperti ladang, kebun, sawah, ataupun lahan milik negara di daerah perbukitan. Aktivitas pertambangan oleh warga ini memang telah memicu polemik dan kontroversi yang termanifestasikan dalam beragam istilah tentangnya beserta latar cara pandang/perspektif seturut basis kepentingan masing-masing. 55

Ditilik dari perspektif konflik, munculnya tiga terminologi itu bisa dibaca sebagai manifestasi ketegangan sosial yang laten dan benang kusut persoalan yang diakibatkan lemahnya peran pemerintah dalam penegakan regulasi. Regulasi yang tidak ditopang oleh konsistensi penegakan hukum hanya akan menciptakan kekarutmarutan. Ditambah dengan praktik pembiaran-boleh jadi pemanfaatan-oleh aparat negara, persoalan tentu saja menjadi semakin kompleks dan rumit untuk diurai. ${ }^{56}$

\section{F. Epilog: Mengkalkulasi Ulang “Will to Improve”}

Sebelum refleksi kritis tersajikan sebagai penutup tulisan, paparan berikut akan terlebih dulu menarik benang merah persoalan terkait pembalikan gaya hidup dan laten konflik warga seputar kawasan tambang. Setidaknya ada delapan catatan penting yang dipetik disini. Pertama, gelombang besar ekonomi pasar telah memicu pertumbuhan budaya konsumerisme, disparitas ekonomi, ketimpangan sosial, dan kecemburuan sosial . Kedua, seiring hempasan gelombang ekonomi pasar itu, tuntuan profesionalitas di dalam kultur industrial secara tidak langsung telah menyemai bibit-bibit individualisme di kalangan buruh, sehingga mendorong terjadinya perubahan radikal atas sistem dan struktur sosio-kultural masyarakat agraris.

Ketiga, peningkatan pendapatan di kalangan buruh secara tidak langsung telah menstimulasi "kebutuhan baru", poligami, di kalangan buruh laki-laki. Maraknya praktek poligami ini merepresentasikan kompleksitas persoalan "ketidakberdayaan" kaum perempuan di ranah domestik maupun publik. Keempat, menguatnya ekonomi pasar telah menstimulasi munculnya diversifikasi sumber ekonomi produktif, terutama sektor jasa, yang menyedot tenaga kerja migran secara masif beserta kompleksitas persoalan sosialnya seperti konsumsi miras, narkoba, kriminalitas, prostitusi, dll. Kelima, heterogenitas

secara berkelompok di lahan mereka send-iri. Ketiga, kalangan pemerintah mengistilahkan ak-tivitas warga semacam itu sebagai praktik "pertam-bangan liar" atau "pertambangan ilegal" yang dinilai menimbulkan pencemaran dan kerusakan lingkun-gan. Dalam perkembangannya, pemerintah mengge-ser terminologi itu dengan "pertambangan tanpa ijin" (PETI).

56 Wawancara warga (Mktr), 30 Oktober 2013 
Jurnal Pemikiran Sosiologi Volume 2 No. 2, 2013

Sampyuh: Genealogi Konflik Industri Ekstraktif di Lanskap Masyarakat Agraris

AB. Widyanta

warga yang tidak dikelola dengan baik telah memicu persoalan baru yang menggerogoti kohesi sosial. Merosotnya modal sosio-kultural, gotongroyong, adalah potret lain dari perubahan gaya hidup warga seputar kawasan tambang.

Keenam, multifaset konflik (seperti konflik warga asli dan pendatang, persaingan dalam pencarian kerja, ketidaksetaraan dalam perlakuan, ketimpangan tingkat penghasilan dan kesejahteran warga, kecemburuan sosial) hanyalah fenomena "pucuk gunung es" persoalan di seputar kawasan tambang. Akar konflik yang sesungguhnya adalah tidak adanya tatakelola yang adekuat bagi terciptanya "kerja bermartabat" untuk seluruh warga. ${ }^{57}$ Ketujuh, beragam rupa tatakelola yang buruk seperti: intransparansi kebijakan, korupsi, kolusi, nepotisme, diskriminasi, dan ketidakadilan merepresentasikan absennya negara atas pengelolaan berbagai sumber daya alam dan sumber- sumber ekonomi produktif di seputar kawasan tambang yang semakin merosot daya topangnya. Kedelapan, masalah pertambangan rakyat adalah eksemplar paling riil dari absennya negara. Eskalasi konflik sumberdaya ini berlangsung dalam arena kontestasi yang timpang dan steril dari upaya-upaya penegakan regulasi secara serius, konsisten, berkelanjutan, dan berkeadilan.

Tersajinya "katalog persoalan" dalam lanskap masyarakat agraris itu merupakan bukti riil atas bekerjanya modus "business as usual" dalam

\footnotetext{
57 Kerja bermartabat merujuk pada arti tentang tiga fungsi kerja, yaitu untuk memberi peluang kepada orang untuk menggunakan dan mengembangkan bakatnya; untuk memampukan orang mengatasi egoismenya dengan cara berbaur dengan orang lain untuk melakukan tugas bersama; dan untuk terus menghasilkan berbagai barang dan jasa yang dibutuhkan untuk kehidupan yang layak. Schumacher. E.F. 1974. Small is Beautiful. A Study
}

ekonomi ekstraktif. Penghancuran kreatif berlangsung nyaris tanpa penghalang karena berbagai aktor dan egensi kelembagaan lokal telah terfragmentasi. Sehingga kultur dan lanskap masyarakat agraris semakin tergusur ke tepian jurang kehancuran. "Katalog persoalan” itu seakan menjadi rujukan representatif dari ilustrasi Peter Goldmark, mantan presiden Rockefeller Foundation, yang menegaskan bahwa "The death of our civilization is no longer a theory or an academic possibility; it is the road we're on."58 Di sini, ilustrasi itu bisa pula ditranslasikan "Sampyuh bukan lagi sekadar suatu kemungkinan akademik ataupun teori, melainkan jalan yang kita tengah tapaki ini."

Bagaimanapun juga, upaya memproblematisasi fenomena konflik sosial dan sampyuh dalam lini masa "kesekarangan" (nowness) merupakan tugas akademik yang perlu ditempuh. Selain memantik kewarasan befikir, hal itu bisa memberi pelajaran berharga bahwa ${ }^{59}$ : pertama, konflik sosial itu menjadi pemicu berbagai prakarsa perubahan kelembagaan sosial dan lingkungan secara lebih progresif; kedua, berbagai karakter dan dampak konflik pada pertambangan sangat tergantung pada persepsi dan prioritas dari lingkaran masing-masing aktor, dan hal itu lebih penting dari yang sesungguhnya terjadi sebagaimana yang dipikirkan dan dinginkan oleh beragam aktor; ketiga, dampak-dampak esktraksi dalam wilayah tertentu dan cara-cara menegosiasikannya sangat

of Economics as if People Mattered. London: Abacus, 1974, hlm. 45-46

${ }^{58}$ Lester R. Brown, World on the Edge: How To Pre-vent Environmental And Economic Collapse, New York: W. W. Norton \& Co, 2011, hlm. 16.

59 Anthony Bebbington, Social Conflict, Economic Development and Extractive Industry Evidence from South America, London: Routledge, 2011, hlm 223 
Jurnal Pemikiran Sosiologi Volume 2 No. 2, 2013

Sampyuh: Genealogi Konflik Industri Ekstraktif di Lanskap Masyarakat Agraris

AB. Widyanta

tergantung dari sejarah ekonomi politik kawasan itu sendiri maupun sejarah ekonomi politik nasional.

Bertolak pada kompleksitas persoalan itu, lantas bagaimana resolusi konflik yang mesti dilakuakan ke depan? Untuk menjawab pertanyaan itu, kita tentu saja akan berhadapan dengan berbagai tantangan normatif. Alih-alih tunggal, resolusi konflik itu tentu saja jamak dan berlapis, mulai dari tataran indivual, kelembagaan, dan kebijakan ekonomi politik nasional, dimana ketiganya terkategorikan dalam tataran kebijakan mikro, messo, dan makro. Bila ditinjau dari aspek program, pada tataran mikro, prakarsa-prakarsa yang perlu dinisiasi bisa mencakup peningkatan stok pengetahuan, penguatan kapasitas dan kesadaran individu tentang pendidikan hak asasi manusia, manajemen konflik, resolusi konflik, dan pembangunan perdamaian, dll.

Pada tataran messo, prakarsa-prakarsa perlu lebih banyak terfokuskan pada upaya pelembagaan atas formasi kesadaran warga tersebut. Misalnya penguatan peran dan fungsi kelembagaan lokal, penguatan dan perluasan jejaring kelembagaan terkait resolusi konflik, dan penguatan pembangunan perdamaian secara partisipatif. Sedangkan pada tataran makro, prakarsa-prakarsa perlu itu lebih penting dari yang sesungguhnya terfokuskan pada upaya advokasi kebijakan yang lebih berpihak pada resolusi konflik dan pembangunan perdamaian. Dengan kata lain, prakarsa di tataran makro jangka panjang itu bertujuan untuk memperkokoh payung dan implementasi kebijakan yang peka konflik dan

${ }^{60}$ Lambang Trijono, Pembangunan Sebagai Perdamaian, Yogyakarta: Padii, 2007, hlm. 59-61. pembangunan perdamaian (peace building mainstreaming). 60

Seluruh prakarsa itu harus bisa memastikan reposisi dan reorientasi model pembangunan yang berhaluan pemberdayaan masyarakat, akar budaya lokal, kearifan lokal, toleransi, dll. Reorientasi model harus berlaku pula pada masterplan reklamasi (paska penutupan tambang) yang mengindahkan klausul-klausul dalam kontrak karya. Hal yang tidak kalah penting adalah perumusan model sistem ekonomi lingkungan (green economy) yang kontekstual untuk Indonesia. Dengan demikian, sejumlah persoalan seperti kerusakan lingkungan, peminggiran kaum miskin, dan merebaknya ghost town di Indonesia bisa terantisipasi.

Tentu saja serangkaian opsi programatik itu merupakan tantangan normatif yang mudah tergelincir ke dalam praktik yang involutif karena tidak dibekali dengan tantangan aktual dan realistis. Tantangan aktual ini akan lebih banyak bersinggungan dengan kontestasi kuasa di antara para aktor di seputar kawasan tambang. Meskipun telah tersaji secara implisit dalam beberapa paparan sebelumnya, namun cara pandang ini tetap dirasa penting untuk dikemukakan di sini agar catatan kesimpulan mendapati keutuhannya.

Melampui opsi-opsi normatif itu, terdapat satu opsi politis yang perlu ditawarkan pula disini, yaitu mengkalkulasi ulang secara seksama atas interaksi multi pihak yang terlibat dalam will to improve di seluruh lingkup ekonomi politik pertambangan, baik di tataran lokal, nasional, dan global-warga 
Jurnal Pemikiran Sosiologi Volume 2 No. 2, 2013

Sampyuh: Genealogi Konflik Industri Ekstraktif di Lanskap Masyarakat Agraris

AB. Widyanta

desa, LSM, organisasi pembangunan, lembagalembaga pemerintah dari berbagai jenjang struktural, sektor privat (kontraktor, subkontraktor, dan GMC). Meminjam penjelasan Li, sekian banyak pihak terlibat dalam will to improve. Mereka menduduki posisi sebagai wakil, suatu posisi yang terdefinisikan oleh klaim untuk mengetahui bagaimana para liyan (others) mesti hidup, apa yang terbaik untuk mereka, dan apa yang mereka butuhkan, yang diekspresikan oleh suatu sumber agensi untuk mengembangkan kapasitas-kapasitas para liyan tersebut."61

Apabila penanda itu kita cocokan kembali dengan "katalog persoalan" warga seputar kawasan tambang diatas, nampaknya mengemuka sebuah kesimpulan yang getir-sebagaimana ditegaskan Li-bahwa upaya merekonsiliasi kapitalisme, konservasi, dan keadilan sosial adalah kemustahilan. Rendahnya kepedulian struktur ekonomi politik negeri ini dan absennya partisipasi warga dalam pengambilan kebijakan di seputar kawasan tambang merupakan bukti penjelas atas simpulan getir itu. ${ }^{62}$

Jika simpulan itu benar, maka sebagai konsekunsi logisnya harus muncul kesimpulan yang berbeda terkait akar konflik warga seputar kawasan tambang. Akar konflik bukan lagi soal karutmarutnya tatakelola sumberdaya alam dan ekonomi produktif di seputar kawasan tambang, melainkan karena akutnya intervensi ekonomi politik global atas ekonomi ekstraktif di negeri ini. Gaduh renegosiasi kontrak tambang rupanya

\footnotetext{
61 Tania Murray Li, The Will to Improve: Governmentality, Development, and the Practice Politics, Duke University Press, 2007, hlm. 4-5.
}

menjadi penanda bahwa negeri ini tetaplah sosok frontier capitalisme yang patuh, sosok wayang yang tak akan bisa lepas dari bayang-bayang intervensi "Dalang" dalam lakon "Sampyuh." Sekarat di pusaran dependensi dan ekploitasi.
62 Baca Mabel Sabogal, Book Reviews Tania Murray Li, The Will to Improve: Governmentality, Development, and the Practice of Politics in Journal of Ecological Anthropology Vol. 13 No. 1 2009, hlm. 80 
Jurnal Pemikiran Sosiologi Volume 2 No. 2, 2013

Sampyuh: Genealogi Konflik Industri Ekstraktif di Lanskap Masyarakat Agraris

AB. Widyanta

\section{Daftar Pustaka}

Bebbington, Anthony. 2011. Social Conflict, Economic Development and Extractive Industry Evidence from South America. London: Routledge.

Becker, Henk A. And Vanclay Frank. 2003. The International Handbook of Social Impact Assessment: Conceptual and Methodological Advances. Cheltenham: Edward Elgar.

Brown, Lester R. 2001. Eco-Economy: Building an Economy for the Earth. New York: W. W. Norton \& Co.

Brown,Lester R. 2011. World on the Edge: How To Prevent Environmental And Economic Collapse. New York: W. W. Norton \& Co

Burke,Melvin. 1982. "We Eat the Mines and the Mines Eat Us: Dependency and Exploitation in Bolivian Tin Mines (book review)" Economics School Faculty Scholarship Paper 10: 693-695.

Costanza,Robert, Graumlich, Lisa J., Steffen, Will. 2007. Sustainability or Collapse: An Integrated History and Future of People on Earth. Cambridge: The MIT Press.

Diamond, Jared. 2005. Collapse: How Societies Choose to Fail or Succeed. New York: Viking-Penguin Diamons, Jared. 1998. Guns, Germs and Steel: Guns, Germs and Steel: A short history of everybody for the last 13,000 years.London: Vintage.

Escobar, Arturo. 1995. Encountering Development: The Making and Unmaking of the Third World. New Jersey: Princeton University Press.

Hardin, Garrett. 1993. Living Within Limits: Ecology, Economics, And Population Taboos. Oxford: Oxford University Press.
Hardin, Garrett. 1968. "The Tragedy of the Unmanaged Commons", Trends in Ecology \& Evolution Volume 9The Tragedy of the Commons in Science , Vol. 162, 13 December Li- Murray, Tania. 2007. The Will to Improve: Governmentality, Development, and the Practice Politics. Duke: Duke University Press.

Nash, June C. 1997. We Eat the Mines and the Mines Eat Us: Dependency and Exploitation in Bolivian Tin Mines. New York: Columbia University Press.

Ostrom, Elinor \& Dols`ak, Nives. 2003. The commons in the new millennium: challenges and adaptation. Cambridge: The MIT Press

Sabogal, Mabel. 2009. "Book Reviews Tania Murray $\mathrm{Li}$, The Will to Improve: Governmentality, Development, and the Practice of Politics", Journal of Ecological Anthropology Vol. 13 No.1

Schumacher, E.F.. 1974. Small is Beautiful: A Study of Economics as if People Mattered. London: Abacus.

Soedjatmoko, Dimensi Manusia dalam Pembangunan. Jakarta: LP3ES, 1983.

Trijono, Lambang. 2007. Pembangunan Sebagai Perdamaian. Yogyakarta: Padii.

Wood, Barbara 1989. E.F.Schumacher His Life and Thought. New York: Harper \& Row Publisher. 
Jurnal Pemikiran Sosiologi Volume 2 No. 2, 2013

Sampyuh: Genealogi Konflik Industri Ekstraktif di Lanskap Masyarakat Agraris

AB. Widyanta

Koran

Kompas, Senin 20 Januari 2014.

Kompas, Jumat 14 Maret 2014

Regulasi

UU No. 4 Tahun 2009 tentang Pertambangan Mineral dan Batubara

Website

Http://finance.detik.com/read/2014/03/04/1523

28/2514972/1034/larang-ekspor-tambang-

mentah-jepang-mau-adukan-ri-ke-wto. Diakses 3 Maret 2014

Http://www.tribunnews.com/bisnis/2014/03/07/

menteri-esdm-renegosiasi-kontrak-tidak-gampang.

Diakses 3 Maret 2014

Htp://www.merdeka.com/uang/5-alibi-

pemerintah-saat-gagal-paksa-freeport-

renegosiasi.html. Dikases 3 Maret 2014.

Http://bisnis.liputan6.com/read/2027893/usai-

pemilu-belasan-perusahaan-tambang-teken-

renegosiasi-kontrak. Diakses 3 Maret 2014.

Http://www.beritaheadline.com/jero-wacikrenegosiasi-kontrak-selesai-tahun-iniutama/3640pemerintah-targetkan-renegosiasi-kontrak-karyaselesai-akhir-2013.html. Diakses Maret 2014.

Http://www.berdikarionline.com/opini/20140228 /quo-vadis-renegosiasi-kontrak pertambangan.html. Diakses 3 Maret 2014. Http://www.tambangnews.com/berita/. Diakses 3 Maret 2014.
Wawancara

Wawancara (Mcw), 30 Oktober 2013;

Wawancara (Mktr), 30 Oktober 2013;

Wawancara (Hmz), 31 Oktober 2013;

Wawancara (Hmz), 11 Februari 2014;

Wawancara (Ttn), 31 Oktober 2013;

Wawancara (Drap), 31 Oktober 2013;

Wawancara (Slmd), 1 November 2013;

Wawancara (Hmz), 1 November 2013;

Wawancara (Sjrw), 1 November 2013;

Wawancara (Habr), 2 November 2013;

Wawancara (Shbd), 2 November 2013;

Wawancara (Mrn), 2 November 2013;

Wawancara (Gun), 2 November 2013;

Wawancara (Wgm), 3 November 2013;

Wawancara (Kds), 3 November 2013;

Wawancara (Abdr), 3 November 2013;

Wawancara (Ern), 3 November 2013;

Wawancara (Mrn), 12 Februrari 2014 